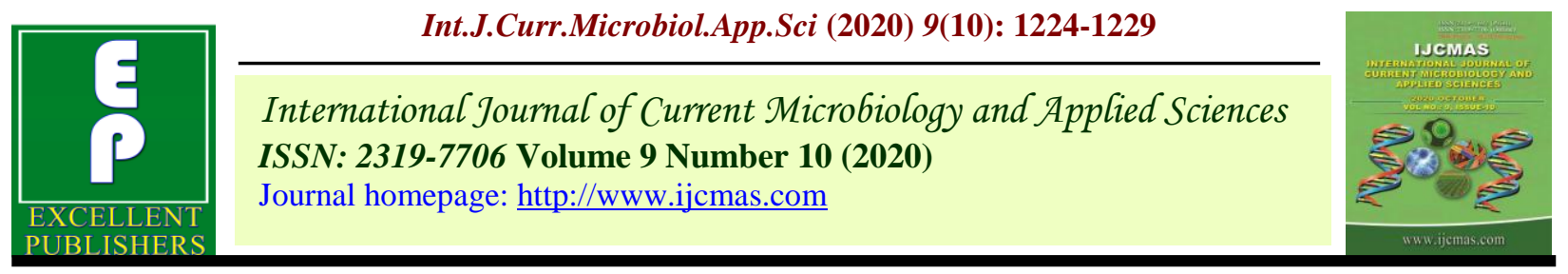

Original Research Article

https://doi.org/10.20546/ijcmas.2020.910.147

\title{
Economic Feasibility of Varied Nitrogen and Potassium Applicationin Eggplant in Middle Gangetic Plains of Bihar
}

\author{
Neelu Kumari ${ }^{1}$, Kamal Kant ${ }^{1}$, Shirin Akhtar ${ }^{1 *}$, Surabhi Sangam ${ }^{1}$, \\ Sunil Kumar ${ }^{2}$, Vijay Kumar Singh ${ }^{1}$, Birendra Kumar ${ }^{3}$ and Randhir Kumar ${ }^{1}$
}

${ }^{1}$ Department of Horticulture (Vegetable and Floriculture), ${ }^{2}$ Department of Soil Science and Agricultural Chemistry, ${ }^{3}$ Department of Agronomy, Bihar Agricultural University, Sabour, Bhagalpur, India

*Corresponding author

\section{A B S T R A C T}

\begin{tabular}{|l|}
\hline Key w o r d s \\
Brinjal, Fertilizer \\
levels, Net income, \\
Benefit: Cost ratio
\end{tabular}

An investigation was designed to study the economic feasibility of use of different varied levels of nitrogenous and potassic fertilizers in eggplant in two new varieties of eggplants, BRBL-01 and BRBL-07. Four levels of $\mathrm{N}\left(\mathrm{N}_{0}-0, \mathrm{~N}_{1}-100, \mathrm{~N}_{2}-120, \mathrm{~N}_{3}-140 \mathrm{~kg} / \mathrm{ha}\right.$; respectively) and $\mathrm{K}$ doses $\left(\mathrm{K}_{0}-0, \mathrm{~K}_{1}-60, \mathrm{~K}_{2}-80, \mathrm{~K}_{3}-100 \mathrm{~kg} / \mathrm{ha}\right.$; respectively) each were taken into consideration and there were total 32 treatment combinations. The cost of cultivation per hectare for the different treatments ranged from INR 123848 to INR 129012, gross income ranged from INR 139020 to INR 432972 per hectare, net income ranged from INR 15172 to INR 304904 per hectare and benefit-cost $(\mathrm{B}: \mathrm{C})$ ratio ranged from $1.12: 1$ to 3.38:1. The gross income, net income and $\mathrm{B}: \mathrm{C}$ ratio were highest in $\mathrm{V}_{1} \mathrm{~N}_{2} \mathrm{~K}_{2}$ (BRBL-01 applied with $120 \mathrm{~kg} / \mathrm{ha} \mathrm{N}, 80 \mathrm{~kg} / \mathrm{ha} \mathrm{K}$ ) and this fertilizer combination was also best for the other variety. Thus, $120 \mathrm{~kg} \mathrm{~N}+80 \mathrm{~kg} \mathrm{~K}$ per hectare could be used for economic benefits to eggplant growers.

\section{Introduction}

Eggplant (Solanum melongenaL.) is one of the most important solanaceous vegetable crops of Indian origin which is also known as brinjal or aubergine (Baigan in Hindi) and grown throughout India around the year. It is an important vegetable crop of central, south and south-east Asia and several African countries. It is good source of vitamin, particularly Vitamin B, and several minerals, viz., $\mathrm{Ca}, \mathrm{P}$ and $\mathrm{Fe}$ etc. From the nutritional point of view, it contains $24 \mathrm{~K}$ cal calories,
$1.4 \mathrm{~g}$ protein, $0.3 \mathrm{~g}$ fat, $4.0 \mathrm{~g}$ carbohydrates, $92.7 \%$ moisture, $18 \mathrm{mg}$ calcium, $47 \mathrm{mg}$ phosphorous, $0.9 \mathrm{mg} \mathrm{Fe}, 122 \mathrm{IU}$ Vit A, 0.04 $\mathrm{mg}$ thiamine, $0.11 \mathrm{mg}$ riboflavin, $0.9 \mathrm{mg}$ niacin and $12 \mathrm{mg}$ ascorbic acid (Thamburaj and Singh, 2013). India produces about 12.80 $\mathrm{mt}$ of brinjal from an area of 0.73 mha with an average productivity of $17.53 \mathrm{t} / \mathrm{ha}$ (Anonymous, 2018). The major brinjal producing states are Odisha, Bihar, Karnataka, West Bengal, Andhra Pradesh, Maharashtra and Uttar Pradesh. 
Eggplant is a long duration crop and heavy feeder. Various researchers have reported various doses of fertilizers for eggplant. Choudhury (1976) opined that a good crop of eggplant required about 84 to $112 \mathrm{~kg} \mathrm{~N}, 84$ to $112 \mathrm{~kg} \mathrm{P}$ and $56 \mathrm{~kg} \mathrm{~K}$ per hectare. The highest yield of brinjal have been reported with 120 $\mathrm{kg} \mathrm{N}+80 \mathrm{~kg}$ each of $\mathrm{P}$ and $\mathrm{K}$ per hectare by Bandopadhyay et al., (1972) in Bihar. Nandekar and Sawarkar (1990) reported that $120 \mathrm{~kg} \mathrm{~N}+75 \mathrm{~kg} \mathrm{P} 2 \mathrm{O} 5+45 \mathrm{~kg} \mathrm{~K} 2 \mathrm{O}$ per hectare produced best vegetative growth and favoured the yield attributes and produced the highest yield. On the other hand, Singh and Syamal (1995).

Eggplant has been reported to give good response to different plant nutrients of the major nutrients, nitrogen and potassium play a vital role in physiology of brinjal resulting in higher yield (Pal et al., 2002). Potassium is an essential nutrient for crops and plays an important role in several physiological processes in plant (Chaitanya et al., 2019).

Application of $\mathrm{N}$ and $\mathrm{K}$ have enhanced the yield and attributing traits in eggplant. But the availability of fertilizers is limited. India imports fertilizers of INR 520.45 billions (Anonymous, 2020). Besides, non-judicious use of fertilizers in crop not only increases the cost of production of the crop, but is also harmful to the environment.

Excessive use of nitrogenous fertilizer often increases the vegetative growth, thereby suppressing the reproductive stage and ultimately the fruit set is affected leading to reduced yield, that ultimately causes economic losses to the growers of the crop.

This investigation was designed to study the economic feasibility of use of different varied levels of nitrogenous and potassic fertilizers in eggplant in two new varieties of eggplant.

\section{Materials and Methods}

The study was conducted at the Vegetable Research Farm, Department of Horticulture (Vegetable and Floriculture), Bihar Agricultural University, Sabour, Bhagalpur (Bihar) during Kharif season of 2018-19 which is the main season of eggplant cultivation.Different levels of nitrogen and potassium were used in combination to study their effect on the yield of two new varieties of eggplant in different segments, viz., BRBL-01 of green oblong segment and BRBL-07 of purple oblong segment. The experiment was laid out in a Factorial Randomized Block Design (FRBD) with three replications maintaining a spacing of $75 \mathrm{~cm}$ between rows and $60 \mathrm{~cm}$ between plants. There were 32 treatments, which were the combinations of three factors variety (V), nitrogen $(\mathrm{N})$ and potassium $(\mathrm{K})$ and there were two varieties $\left(\mathrm{V}_{1}\right.$ :BRBL-01, $\mathrm{V}_{2}$ :BRBL$07)$, four nitrogen doses $\left(\mathrm{N}_{0}: 0 \mathrm{~kg} / \mathrm{ha}, \mathrm{N}_{1}: 100\right.$ $\mathrm{kg} / \mathrm{ha}, \mathrm{N}_{2}: 120 \mathrm{~kg} / \mathrm{ha}, \mathrm{N}_{3}: 140 \mathrm{~kg} / \mathrm{ha}$ ) and four potassium doses $\left(\mathrm{K}_{0}: 0 \mathrm{~kg} / \mathrm{ha}, \mathrm{K}_{1}: 60 \mathrm{~kg} / \mathrm{ha}, \mathrm{K}_{2}\right.$ : $80 \mathrm{~kg} / \mathrm{ha}, \mathrm{K}_{3}: 100 \mathrm{~kg} / \mathrm{ha}$, respectively). A fixed dose of $80 \mathrm{~kg} / \mathrm{ha} \mathrm{P}$ was applied to all the plots as basal dose in form of single super phosphate (SSP). Besides, the total dose of K fertilizer as per treatment, in form of muriate of potash (MOP), was also applied as basal dose. Half the nitrogenous fertilizer in form of urea was applied as basal dose as per treatment in each plot. The remaining half as urea was applied in three split doses at 30 days after transplanting (DAT), 60 DAT and 90 DAT as topdress.

The plot yield was recorded as per treatment and converted to kilograms per hectare. The total cost of cultivation was calculated incorporating the cost of all inputs, land preparation, manpower, fixed costs, etc. The average selling rate (farm gate price) of eggplant was fixed as INR 12.00 per kilogram and gross income estimated from it. 
Gross income $=$ Yield $\times$ Selling rate

The net income was generated by subtracting the production cost from the gross income.

Net income $=$ Gross income - Cost of cultivation

The benefit: cost $(\mathrm{B}: \mathrm{C})$ ratio was estimated by the following formula:

$\mathrm{B}: \mathrm{C}$ ratio $=\frac{\text { Gross income }}{\text { Cost of cultivation }}$

\section{Results and Discussion}

The cost of cultivation per hectare for the different treatments ranged from INR 123848 to INR 129012. Among the various treatments under study, the production cost was found to be highest in the treatment of $140 \mathrm{~kg} / \mathrm{ha} \mathrm{N}+$ $100 \mathrm{~kg} / \mathrm{ha} \mathrm{K}$ for both varieties BRBL-01 and BRBL-07. This was followed by $120 \mathrm{~kg} / \mathrm{ha} \mathrm{N}$ $+100 \mathrm{~kg} / \mathrm{ha} \mathrm{K}, 100 \mathrm{~kg} / \mathrm{ha} \mathrm{N}+100 \mathrm{~kg} / \mathrm{ha} \mathrm{K}$, $140 \mathrm{~kg} / \mathrm{ha} \mathrm{N}+80 \mathrm{~kg} / \mathrm{ha} \mathrm{K}, 120 \mathrm{~kg} / \mathrm{ha} \mathrm{N}+80$ $\mathrm{kg} / \mathrm{ha} \mathrm{K}$ for both varieties.

Significant differences in yield in the different treatments was observed. The variety BRBL07 was found to be higher yielder than variety BRBL-07.

The trend of yield was found increasing with increment of doses of nitrogen and potassium but $\mathrm{K}$ level beyond $80 \mathrm{~kg} / \mathrm{ha}$ showed slight decline in yield.

The gross income ranged from INR 139020 to INR 432972 per hectare. The maximum gross income was obtained in BRBL-01 treated with $120 \mathrm{~kg} / \mathrm{ha} \mathrm{N}+80 \mathrm{~kg} / \mathrm{ha} \mathrm{K}$, followed by BRBL-07 applied with $140 \mathrm{~kg} / \mathrm{ha} \mathrm{N}+80$ $\mathrm{kg} / \mathrm{ha} \mathrm{K}$, followed by BRBL-07 treated with $120 \mathrm{~kg} / \mathrm{ha} \mathrm{N}+80 \mathrm{~kg} / \mathrm{ha} \mathrm{K}$, followed by BRBL-01 applied with $140 \mathrm{~kg} / \mathrm{ha} \mathrm{N}+80$ $\mathrm{kg} / \mathrm{ha} \mathrm{K}$. The least gross income was obtained in BRBL-01 without any application of $\mathrm{N}$ and $\mathrm{K}$ fertilizers followed by BRBL-07 without any $\mathrm{N}$ and $\mathrm{K}$ treatment.

The net income ranged from INR 15172 to INR 304904 per hectare. Net income was maximum in the treatment $\mathrm{V}_{1} \mathrm{~N}_{2} \mathrm{~K}_{2}$ (BRBL-01 applied with $120 \mathrm{~kg} / \mathrm{ha} \quad \mathrm{N}, 80 \mathrm{~kg} / \mathrm{ha} \quad \mathrm{K}$ ) followed by treatment $\mathrm{V}_{2} \mathrm{~N}_{3} \mathrm{~K}_{2}$ (BRBL-07 applied with $140 \mathrm{~kg} / \mathrm{ha} \mathrm{N}, 80 \mathrm{~kg} / \mathrm{ha} \mathrm{K}$ ), $\mathrm{V}_{2} \mathrm{~N}_{2} \mathrm{~K}_{2}$ (BRBL-07 applied with $120 \mathrm{~kg} / \mathrm{ha} \mathrm{N}$, $80 \mathrm{~kg} / \mathrm{ha} \mathrm{K}$ ), $\mathrm{V}_{1} \mathrm{~N}_{3} \mathrm{~K}_{2}$ (BRBL-01 applied with $140 \mathrm{~kg} / \mathrm{ha} \mathrm{N}, 80 \mathrm{~kg} / \mathrm{ha} \mathrm{K}), \mathrm{V}_{1} \mathrm{~N}_{3} \mathrm{~K}_{1}$ (BRBL-01 applied with $140 \mathrm{~kg} / \mathrm{ha} \mathrm{N}, 60 \mathrm{~kg} / \mathrm{ha} \mathrm{K}$ ) and $\mathrm{V}_{1} \mathrm{~N}_{2} \mathrm{~K}_{3}$ (BRBL-01 applied with $120 \mathrm{~kg} / \mathrm{ha} \mathrm{N}$, $100 \mathrm{~kg} / \mathrm{ha} \mathrm{K}$ ). On the other hand, net income was minimum in the treatment $\mathrm{V}_{1} \mathrm{~N}_{0} \mathrm{~K}_{0}$ (BRBL-01without application of $\mathrm{N}$ and $\mathrm{K}$ ) followed by treatment $\mathrm{V}_{2} \mathrm{~N}_{0} \mathrm{~K}_{0}$ (BRBL-07 without application of $\mathrm{N}$ and $\mathrm{K}$ ).

The benefit-cost $(\mathrm{B}: \mathrm{C})$ ratio ranged from $1.12: 1$ to $3.38: 1$. Among all the treatments, the highestbenefit-cost ratio (B:C) of 3.38:1 was recorded in the treatment $\mathrm{V}_{1} \mathrm{~N}_{2} \mathrm{~K}_{2}$ (BRBL-01 applied with $120 \mathrm{~kg} / \mathrm{ha} \quad \mathrm{N}, 80 \mathrm{~kg} / \mathrm{ha} \quad \mathrm{K}$ ) followed by treatment $\mathrm{V}_{2} \mathrm{~N}_{3} \mathrm{~K}_{2} \quad(3.33: 1$ in BRBL-07 applied with $140 \mathrm{~kg} / \mathrm{ha} \mathrm{N}, 80 \mathrm{~kg} / \mathrm{ha}$ $\mathrm{K}), \mathrm{V}_{2} \mathrm{~N}_{2} \mathrm{~K}_{2}$ (3.32:1 in BRBL-07 applied with $120 \mathrm{~kg} / \mathrm{ha} \mathrm{N}, 80 \mathrm{~kg} / \mathrm{ha} \mathrm{K}), \mathrm{V}_{1} \mathrm{~N}_{3} \mathrm{~K}_{2}$ (3.28:1 in BRBL-01 applied with $140 \mathrm{~kg} / \mathrm{ha} \mathrm{N}, 80 \mathrm{~kg} / \mathrm{ha}$ $\mathrm{K}), \mathrm{V}_{1} \mathrm{~N}_{3} \mathrm{~K}_{1}$ (3.19:1 in BRBL-01 applied with $140 \mathrm{~kg} / \mathrm{ha} \mathrm{N}, 60 \mathrm{~kg} / \mathrm{ha} \mathrm{K})$ and $\mathrm{V}_{1} \mathrm{~N}_{2} \mathrm{~K}_{3}(3.14: 1$ BRBL-01 applied with $120 \mathrm{~kg} / \mathrm{ha} \mathrm{N}, 100 \mathrm{~kg} / \mathrm{ha}$ $\mathrm{K})$. On the other hand,benefit-cost ratio (B:C) was minimum in the treatment $\mathrm{V}_{1} \mathrm{~N}_{0} \mathrm{~K}_{0}(1.12: 1$ in BRBL-01 without application of $\mathrm{N}$ and $\mathrm{K}$ ) followed by treatment $\mathrm{V}_{2} \mathrm{~N}_{0} \mathrm{~K}_{0}(1.18: 1$ in BRBL-07 without application of $\mathrm{N}$ and $\mathrm{K})$.This was followed by $\mathrm{V}_{1} \mathrm{~N}_{0} \mathrm{~K}_{1}(1.31: 1$ BRBL-01 applied with $120 \mathrm{~kg} / \mathrm{ha} \mathrm{N}, 100 \mathrm{~kg} / \mathrm{ha}$ $\mathrm{K}), \mathrm{V}_{1} \mathrm{~N}_{0} \mathrm{~K}_{3}(1.36: 1 \mathrm{BRBL}-01$ applied with 120 $\mathrm{kg} / \mathrm{ha} \mathrm{N}, 100 \mathrm{~kg} / \mathrm{ha} \mathrm{K}), \mathrm{V}_{2} \mathrm{~N}_{0} \mathrm{~K}_{3}(1.45: 1 \mathrm{BRBL}-$ 01 applied with $120 \mathrm{~kg} / \mathrm{ha} \mathrm{N}, 100 \mathrm{~kg} / \mathrm{ha} \mathrm{K}$ ), $\mathrm{V}_{2} \mathrm{~N}_{0} \mathrm{~K}_{1}(1.48: 1$ BRBL-01 applied with 120 $\mathrm{kg} / \mathrm{ha} \mathrm{N}, 100 \mathrm{~kg} / \mathrm{ha} \mathrm{K}$ ) (Table 1). 
Table.1 Effect of different varieties of brinjal, and different levels of $\mathrm{N}$ and KOn economics of different treatments and benefit:cost ratio

\begin{tabular}{|c|c|c|c|c|c|c|c|}
\hline & Treatments & $\begin{array}{c}\text { Yield } \\
\text { (kg/ha) }\end{array}$ & $\begin{array}{c}\text { Average } \\
\text { Selling } \\
\text { rate } \\
\text { (Rs./kg) }\end{array}$ & $\begin{array}{c}\text { Gross } \\
\text { income } \\
\text { (Rs./ha) (A) }\end{array}$ & $\begin{array}{l}\text { Total cost of } \\
\text { cultivation } \\
\text { (Rs./ha) (B) }\end{array}$ & $\begin{array}{l}\text { Net income } \\
\text { (Rs./ha) (A- } \\
\text { B) }\end{array}$ & $\begin{array}{c}\text { B:C } \\
\text { Ratio }\end{array}$ \\
\hline$T_{1}$ & $\mathbf{V}_{1} \mathbf{N}_{0} \mathbf{K}_{0}$ & 11585.00 & 12.00 & 139020.00 & 123848.00 & 15172.00 & 1.12 \\
\hline $\mathbf{T}_{2}$ & $\mathbf{V}_{1} \mathbf{N}_{0} \mathbf{K}_{1}$ & 13842.33 & 12.00 & 166104.00 & 125848.00 & 40256.00 & 1.32 \\
\hline $\mathbf{T}_{3}$ & $\mathbf{V}_{1} \mathbf{N}_{0} \mathbf{K}_{2}$ & 17026.00 & 12.00 & 204312.00 & 126508.00 & 77804.00 & 1.62 \\
\hline $\mathbf{T}_{4}$ & $\mathbf{V}_{1} \mathbf{N}_{\mathbf{0}} \mathbf{K}_{3}$ & 14459.67 & 12.00 & 173508.00 & 127188.00 & 46320.00 & 1.36 \\
\hline $\mathbf{T}_{5}$ & $\mathbf{V}_{1} \mathbf{N}_{1} \mathbf{K}_{0}$ & 16373.33 & 12.00 & 196476.00 & 125150.00 & 71326.00 & 1.57 \\
\hline $\mathbf{T}_{6}$ & $\mathbf{V}_{1} \mathbf{N}_{1} \mathbf{K}_{1}$ & 27295.33 & 12.00 & 327540.00 & 127150.00 & 200390.00 & 2.58 \\
\hline $\mathbf{T}_{7}$ & $\mathbf{V}_{1} \mathbf{N}_{1} \mathbf{K}_{2}$ & 32590.67 & 12.00 & 391080.00 & 127810.00 & 263270.00 & 3.06 \\
\hline $\mathbf{T}_{8}$ & $\mathbf{V}_{1} \mathbf{N}_{1} \mathbf{K}_{3}$ & 30352.33 & 12.00 & 364224.00 & 128490.00 & 235734.00 & 2.83 \\
\hline $\mathbf{T}_{9}$ & $\mathbf{V}_{1} \mathbf{N}_{2} \mathbf{K}_{0}$ & 16631.33 & 12.00 & 199572.00 & 125408.00 & 74164.00 & 1.59 \\
\hline$T_{10}$ & $\mathbf{V}_{1} \mathbf{N}_{2} \mathbf{K}_{1}$ & 31989.67 & 12.00 & 383868.00 & 127408.00 & 256460.00 & 3.01 \\
\hline$T_{11}$ & $\mathbf{V}_{1} \mathbf{N}_{2} \mathbf{K}_{2}$ & 36081.00 & 12.00 & 432972.00 & 128068.00 & 304904.00 & 3.38 \\
\hline $\mathbf{T}_{12}$ & $\mathbf{V}_{1} \mathbf{N}_{2} \mathbf{K}_{3}$ & 33784.00 & 12.00 & 405408.00 & 128748.00 & 276660.00 & 3.15 \\
\hline $\mathbf{T}_{13}$ & $\mathbf{V}_{1} \mathbf{N}_{3} K_{0}$ & 19079.67 & 12.00 & 228948.00 & 125672.00 & 103276.00 & 1.82 \\
\hline$T_{14}$ & $\mathbf{V}_{1} \mathbf{N}_{3} K_{1}$ & 33984.67 & 12.00 & 407808.00 & 127672.00 & 280136.00 & 3.19 \\
\hline$T_{15}$ & $\mathbf{V}_{1} \mathbf{N}_{3} K_{2}$ & 35153.33 & 12.00 & 421836.00 & 128332.00 & 293504.00 & 3.29 \\
\hline$T_{16}$ & $\mathbf{V}_{1} \mathbf{N}_{3} K_{3}$ & 32316.00 & 12.00 & 387792.00 & 129012.00 & 258780.00 & 3.01 \\
\hline$T_{17}$ & $\mathbf{V}_{2} \mathbf{N}_{0} \mathbf{K}_{\mathbf{0}}$ & 11824.75 & 12.00 & 141888.00 & 123848.00 & 18040.00 & 1.15 \\
\hline $\mathbf{T}_{18}$ & $\mathbf{V}_{2} \mathbf{N}_{0} \mathbf{K}_{1}$ & 15570.89 & 12.00 & 186840.00 & 125848.00 & 60992.00 & 1.48 \\
\hline $\mathbf{T}_{19}$ & $\mathbf{V}_{2} \mathbf{N}_{0} K_{2}$ & 17771.11 & 12.00 & 213252.00 & 126508.00 & 86744.00 & 1.69 \\
\hline $\mathbf{T}_{20}$ & $\mathbf{V}_{2} \mathbf{N}_{0} \mathbf{K}_{3}$ & 15456.98 & 12.00 & 185472.00 & 127188.00 & 58284.00 & 1.46 \\
\hline$T_{21}$ & $\mathbf{V}_{2} \mathbf{N}_{1} \mathbf{K}_{0}$ & 24281.46 & 12.00 & 291372.00 & 125150.00 & 166222.00 & 2.33 \\
\hline $\mathbf{T}_{22}$ & $\mathbf{V}_{2} \mathbf{N}_{1} \mathbf{K}_{1}$ & 27567.67 & 12.00 & 330804.00 & 127150.00 & 203654.00 & 2.60 \\
\hline $\mathbf{T}_{23}$ & $\mathbf{V}_{2} \mathbf{N}_{1} K_{2}$ & 31514.38 & 12.00 & 378168.00 & 127810.00 & 250358.00 & 2.96 \\
\hline $\mathbf{T}_{24}$ & $\mathbf{V}_{2} \mathbf{N}_{1} K_{3}$ & 24533.98 & 12.00 & 294396.00 & 128490.00 & 165906.00 & 2.29 \\
\hline$T_{25}$ & $\mathbf{V}_{2} \mathbf{N}_{2} \mathbf{K}_{\mathbf{0}}$ & 25454.91 & 12.00 & 305448.00 & 125408.00 & 180040.00 & 2.44 \\
\hline$T_{26}$ & $\mathbf{V}_{2} \mathbf{N}_{2} \mathbf{K}_{1}$ & 29361.54 & 12.00 & 352332.00 & 127408.00 & 224924.00 & 2.77 \\
\hline $\mathbf{T}_{27}$ & $\mathbf{V}_{2} \mathbf{N}_{2} K_{2}$ & 35516.20 & 12.00 & 426192.00 & 128068.00 & 298124.00 & 3.33 \\
\hline$T_{28}$ & $\mathbf{V}_{2} \mathbf{N}_{2} K_{3}$ & 25242.68 & 12.00 & 302904.00 & 128748.00 & 174156.00 & 2.35 \\
\hline$T_{29}$ & $\mathbf{V}_{2} \mathbf{N}_{3} \mathbf{K}_{\mathbf{0}}$ & 32038.08 & 12.00 & 384456.00 & 125672.00 & 258784.00 & 3.06 \\
\hline $\mathbf{T}_{30}$ & $\mathbf{V}_{2} \mathbf{N}_{3} \mathbf{K}_{1}$ & 32439.95 & 12.00 & 389268.00 & 127672.00 & 261596.00 & 3.05 \\
\hline $\mathbf{T}_{31}$ & $\mathbf{V}_{2} \mathbf{N}_{3} \mathbf{K}_{2}$ & 35687.96 & 12.00 & 428244.00 & 128332.00 & 299912.00 & 3.34 \\
\hline$T_{32}$ & $\mathbf{V}_{2} \mathbf{N}_{3} K_{3}$ & 32287.83 & 12.00 & 387444.00 & 129012.00 & 258432.00 & 3.00 \\
\hline
\end{tabular}

Note: $\mathrm{V}_{1}:$ BRBL-01, $\mathrm{V}_{2}: B R B L-07, \mathrm{~N}_{0}: 0 \mathrm{~kg} / \mathrm{ha}, \mathrm{N}_{1}: 100 \mathrm{~kg} / \mathrm{ha}, \mathrm{N}_{2}: 120 \mathrm{~kg} / \mathrm{ha}, \mathrm{N}_{3}: 140 \mathrm{~kg} / \mathrm{ha}, \mathrm{K}_{0}: 0 \mathrm{~kg} / \mathrm{ha}, \mathrm{K}_{1}: 60 \mathrm{~kg} / \mathrm{ha}$, $\mathrm{K}_{2}: 80 \mathrm{~kg} / \mathrm{ha}, \mathrm{K}_{3}: 100 \mathrm{~kg} / \mathrm{ha}$

Cost of cultivation varied between the different treatments under study. The higher price of potassic fertilizers was reflected through this production cost, which led to the 
enhanced cost of cultivation in the treatments with higher levels of K. Greenwood (1974) and Rahman et al., (2016) previously identified chemical fertilizer cost as one of the major factors determining the production cost in eggplant.

Significant differences in yield in the different treatments were observed. The variety BRBL07 was found to be higher yielder than variety BRBL-07. The trend of yield was found increasing with increment of doses of nitrogen and potassium but $\mathrm{K}$ level beyond 80 $\mathrm{kg} / \mathrm{ha}$ showed slight decline in yield.

The gross income ranged from INR 139020 to INR 432972 per hectare. Rahman et al., (2016) in Jamalpur district of Bangladesh reported that the gross return from eggplant cultivation was Taka 461954.45. The maximum gross income was obtained in BRBL-01 treated with $120 \mathrm{~kg} / \mathrm{ha} \mathrm{N}+80$ $\mathrm{kg} / \mathrm{ha} \mathrm{K}$, followed by BRBL-07 applied with $140 \mathrm{~kg} / \mathrm{ha} \mathrm{N}+80 \mathrm{~kg} / \mathrm{ha} \mathrm{K}$, followed by BRBL-07 treated with $120 \mathrm{~kg} / \mathrm{ha} \mathrm{N}+80$ $\mathrm{kg} / \mathrm{ha} \mathrm{K}$, followed by BRBL-01 applied with $140 \mathrm{~kg} / \mathrm{ha} \mathrm{N}+80 \mathrm{~kg} / \mathrm{ha} \mathrm{K}$. The least gross income was obtained in BRBL-01 without any application of $\mathrm{N}$ and $\mathrm{K}$ fertilizers followed by BRBL-07 without any $\mathrm{N}$ and $\mathrm{K}$ treatment. Higher levels of gross income were obtained with fertilizer application since it led to increment of yield. Rahman et al., (2011) also reported enhanced gross return with increased rates of fertilizer application.

The net income ranged from INR 15172 to INR 304904 per hectare. The earlier work of Rahman et al., (2016) showed that the net return from eggplant cultivation was Taka 317297.97. Net income was highest in treatments with $80 \mathrm{~kg} / \mathrm{ha}$ potassic fertilizers and there was decline with higher doses. This was due to decline in yield at higher $\mathrm{K}$ levels and higher cost of potassic fertilizers. The benefit-cost ratio net reflected the net income, which is in accordance with Rymbai et al., (2012). The benefit-cost (B:C) ratio ranged from 1.12:1 to 3.38:1. Rahman et al., (2016) reported that the $\mathrm{B}: \mathrm{C}$ ratio for eggplant cultivation in Jamalpur district of Bangladesh was 3.29, and cultivation this crop could be a remunerative enterprise. BRBL-01 applied with $120 \mathrm{~kg} / \mathrm{ha}$ nitrogen, $80 \mathrm{~kg} / \mathrm{ha}$ potassium give the highest net income and benefit cost Ratio (B:C) whereas the same variety without application of $\mathrm{N}$ and $\mathrm{K}$ produced the least. This same dose yielded the highest net income and benefit cost ratio (B:C) for the other variety BRBL-07 also. Thus, for economic benefit to growers, application of $120 \mathrm{~kg} / \mathrm{ha} \mathrm{N}$ and $80 \mathrm{~kg} / \mathrm{ha} \mathrm{K}$ may be recommended.

\section{Acknowledgement}

The authors are thankful to the Department of Horticulture (Vegetable and Floriculture), Bihar Agricultural University, Sabour for providing infrastructure for the study. The authors also acknowledge the BAU, Sabour non-plan project $\mathrm{SNP} / \mathrm{CI} / \mathrm{Kh} / 2016-12$ for financial support for the research work.

\section{References}

Anonymous. 2018. Horticultural statistics at a glance 2018. Horticulture Statistics Division, Department of Agriculture, Cooperation and Farmer's Welfare, Ministry of India, Government of India.

Anonymous. 2020. Value of India's fertilizer imports from FY 2011 to FY 2019. Statistica, https://www.statista.com/ statistics/625203/import-value-of-

fertilizer-india/ accessed on $19^{\text {th }}$ September, 2020.

Bandopadhyay, C.R., Bid, N.N. and Das, P.K. 1972. Study on the response of brinjal, tomato and onion to nitrogen phosphorus and potash application. 
Proc. of $3^{\text {rd }}$ Inter. Symp. Trop. and Subtrop. Hort. Bangalore, Feb., 1972. Pp. 149-159.

Chaitanya, T., Padmaja, G., and Rao, P.C. 2019Potassium in Relation to Yield, Quality and Economics of Brinjal Cabbage Cropping System. International Journal of Current Microbiology and Applied Sciences. 8(4):2319-7706.

Choudhury, B. (1976). Vegetables ( $4^{\text {th }}$ edn.), National Book Trust, New Delhi, India, pp. 50-58.

Greenwood, D.J. 1974. The Fertilizer Society. Fertilizer requirements of vegetable crops. Proc. 145th, London, 30.

Nandekar, D.N., and Sawarkar, S.D. 1990. Effect of plant nutrients (NPK) on different varieties of brinjal (Solanum melongena L.). Orissa Journal of Horticulture. 18: 1-5.

Pal, S., Saimbiil, M., and Bal S.S. 2002. Effect of nitrogen and phosphorus levels on growth and yield of brinjal hybrids (Solanum melongena L.). Vegetable Science. 29 (1):90-91.

Rahman, M.H., Islam, M.R., Jahiruddin, M.,
Haque, M.Q. 2011. Economics of fertilizer use in maize-mungbeandhaincha-T.aman rice cropping pattern. Journal of Bangladesh Agricultural University. 9 (1): 37-42.

Rahman, M.Z., Kabir, H., and Khan, M. 2016.A study on brinjal production in Jamalpur district through profitability analysis and factors affecting the production. Journal of Bangladesh Agricultural University. 14(1): 113118.

Rymbai, D., Singh, R., Feroze, S.M., Bardoloi, R. 2012. Benefit-cost analysis of pineapple orchard in Meghalaya. Indian Journal of Hill Farming. 25 (1): 9-12.

Singh, V.N., and Syamal, M.M. 1995. Effect of $\mathrm{N}$ and spacing on yield and quality attributes of brinjal. Journal of Research Birsa Agricultural University. 7: 137-139.

Thamburaj, S., and Singh, N. 2013. Textbook of vegetables, tubercrops and spices, published by Directorate of Knowledge Management in agriculture, ICAR, New Delhi.

\section{How to cite this article:}

Neelu Kumari, Kamal Kant, Shirin Akhtar, Surabhi Sangam, Sunil Kumar, Vijay Kumar Singh, Birendra Kumar and Randhir Kumar. 2020. Economic Feasibility of Varied Nitrogen and Potassium Application in Eggplant in Middle Gangetic Plains of Bihar. Int.J.Curr.Microbiol.App.Sci. 9(10): 1224-1229. doi: https://doi.org/10.20546/ijcmas.2020.910.147 